\title{
Variation in the population genetic structure of two Cyclamen species on the island of Corsica
}

\author{
LAURENCE AFFRE \& JOHN D. THOMPSON* \\ C.E.F.E.C.N.R.S., Route de Mende, BP 5051, F-34033 Montpellier Cédex 1, France
}

\begin{abstract}
Cyclamen repandum and $C$. hederifolium occur in sympatry in many sites across their distributions but flower at different times. A previous controlled pollination experiment on plants of the two species collected on the island of Corsica showed no evidence of inbreeding depression over all measured life cycle stages in $C$. repandum, whereas $C$. hederifolium showed inbreeding depression (multiplicative $\delta=0.49$ ) on fruit maturation and seed production. This suggests that $C$. repandum may have a greater history of inbreeding than $C$. hederifolium. In this paper, we examine whether within-population heterozygosity and among-population differentiation on Corsica are consistent with the hypothesis that $C$. repandum is more inbred than $C$. hederifolium. Cyclamen hederifolium showed a higher percentage of polymorphic loci, mean number of alleles per locus and mean observed heterozygosity than $C$. repandum. Cyclamen repandum showed higher among population differentiation $\left(F_{\mathrm{ST}}=0.415\right)$ than $C$. hederifolium $\left(F_{\mathrm{ST}}=0.131\right)$. The within-population fixation index was greater in $C$. repandum $\left(F_{\mathrm{IS}}=0.658\right)$ than in $C$. hederifolium $\left(F_{\mathrm{IS}}=0.329\right)$. Cyclamen repandum thus appears to have a greater history of inbreeding than $C$. hederifolium. The variation in the mating system of the two species is discussed in relation to their sympatric occurrence and data from previous work on the population genetic structure of island populations of other geographically restricted $C y c l a-$ men species
\end{abstract}

Keywords: Cyclamen, genetic variation, mating system, population differentiation, Primulaceae, sympatry.

\section{Introduction}

There is now much evidence that mating system and geographical distribution are major determinants of the amounts and spatial patterns of genetic variability in plant species. Geographically widespread, outcrossing animal-pollinated species tend to have higher levels of genetic variation within populations and to maintain lower levels of differentiation among populations than restricted, inbreeding species (Hamrick et al., 1979; Loveless \& Hamrick, 1984; Karron, 1987, 1991; Hamrick \& Godt, 1989). Geographically restricted species have also been found to have higher rates of self-pollination (Karron, 1987, 1991).

Some restricted species do, however, contain relatively high levels of genetic variation (Primack, 1980;

*Correspondence. E-mail: thompson@cefe.cnrs-mop.fr

(C) 1997 The Genetical Society of Great Britain.
Linhart \& Premoli, 1993) and Karron (1987) has pointed out the difficulty of drawing conclusions about such predictions from studies of unrelated taxa. A useful approach to the study of the relationship between mating system, geographical distribution and patterns of genetic diversity is thus the comparison of closely related taxa.

Within the genus Cyclamen (Primulaceae), $C$. repandum ssp. repandum (hereafter $C$. repandum) and $C$. hederifolium are widely distributed across the northern Mediterranean Basin. Cyclamen repandum occurs from southern France, through Italy, to the western side of ex-Yugoslavia (Dalmatia) and Greece, and $C$. hederifolium occurs from southern France to eastern Bulgaria and southern Turkey and on several Aegean islands. Both species also occur on the islands of Corsica, Sardinia and Sicily (GreyWilson, 1988). On Corsica, $C$. repandum and $C$. hederifolium are sympatric, occurring in a wide range 
of similar habitats and frequently in the same sites. Nevertheless, the two species flower at different times of the year, $C$. repandum in the spring and $C$. hederifolium in the autumn.

Both $C$. repandum and $C$. hederifolium are fully self-compatible but set almost no fruit in the absence of external pollinating agents (Affre, 1996). In a controlled pollination trial, $C$. repandum showed no evidence of inbreeding depression on fruit maturation and seed number (multiplicative estimate of $\delta=0.14$ ), whereas $C$. hederifolium showed a multiplicative estimate of inbreeding depression equal to 0.49 (Affre, 1996). These results suggest that $C$. hederifolium is an outcrossing species, whereas $C$. repandum appears to be more autogamous and may show high levels of pollinatormediated inbreeding in natural populations. The first purpose of this study is thus to compare levels of genetic variation and differentiation within and among populations of both species across a range of sites on Corsica where they are sympatric. Explicitly, we examine whether $C$. hederifolium shows higher levels of within-population diversity and heterozygosity and less among-population differentiation than C. repandum.

A recent phylogenetic analysis of Cyclamen species based on morphological and cytological traits (Anderberg, 1993) indicates that $C$. repandum is closely related to $C$. balearicum and $C$. creticum. Cyclamen hederifolium is in a separate group with several other related species of more eastern and central Mediterranean distribution.

Previous studies of the population genetic structure of the two species closely related to $C$. repan$d u m$ have shown that $C$. balearicum has a mean $F_{\text {IS }}$ close to 1.00 in most populations and a mean $F_{\mathrm{ST}}$ of $0.297 \pm 0.059$ on the Balearic Islands and $0.480 \pm 0.101$ in southern France (Affre et al., 1997), whereas $C$. creticum has a mean $F_{\mathrm{IS}}=0.748 \pm 0.068$ and a mean $F_{\text {ST }}$ of $0.168 \pm 0.028$ on Crete (Affre \& Thompson, 1997). Cyclamen balearicum and C. creticum have very narrow ranges $(C$. balearicum occurs on the Balearic Islands and in several isolated sites in southern France and C. creticum occurs on Crete and Karpathos) compared with $C$. repandum and $C$. hederifolium. We ask two secondary questions. First, do the two endemic species, $C$. balearicum and $C$. creticum, exhibit lower levels of genetic variability than the two widespread species, C. repandum and $C$. hederifolium? Secondly, because $C$. balearicum is the only species of the four capable of spontaneous self-pollination, does this species exhibit greater heterozygote deficiency and genetic differentiation than $C$. creticum, $C$. repandum and $C$. hederifolium?

\section{Materials and methods}

\section{Study species}

Cyclamen repandum Sibth. \& $\mathrm{Sm}$. and $C$. hederifolium Aiton are long-lived, perennial herbaceous plant species. Cyclamen repandum $(2 n=20)$ and $C$. hederifolium $(2 n=34)$ are both diploid species, although the latter is known to have polyploid forms in Greece (Bennett \& Grimshaw, 1991). In both species, the flowers are solitary, pendant with reflexed petals, hermaphroditic and do not produce nectar. Cyclamen repandum flowers in the spring (March-May), whereas $C$. hederifolium flowers in the autumn (from the end of August until October or occasionally later) before the leaves emerge. In the CEFE-CNRS experimental garden in Montpellier (France), C. repandum plants produce from one to 11 (mean $=5.3 \pm 0.4$ ) vivid carmine-magenta flowers with narrow, twisting petals. The style is exserted beyond the mouth of the corolla. Cyclamen hederifolium plants produce from one to 39 (mean $=9.2 \pm 0.9)$ pink flowers with a purplemagenta blotch forming a V-shape at the base of each corolla lobe. The style is slightly exserted beyond the mouth of the corolla.

\section{Enzyme electrophoresis}

On Corsica, the populations of both studied species were sampled from 10 to $940 \mathrm{~m}$ (C. repandum) or to $1150 \mathrm{~m} \mathrm{(C.} \mathrm{hederifolium).} \mathrm{Two} \mathrm{or} \mathrm{three} \mathrm{leaves} \mathrm{per}$ individual were sampled in eight populations of $C$. repandum in April 1993 and in seven populations of C. hederifolium in October 1993. Four sites (BF: Bas Fango (175 m); HF: Haut Fango (350 m); VE: Vecchio $(850 \mathrm{~m})$; and RE: Restonica $(940 \mathrm{~m})$ ) contained both species. Four sites contained only $C$. repandum (PO: Portigliolo $(10 \mathrm{~m})$; CA: Capitelle $(40 \mathrm{~m})$; NI: Nichiareto $(90 \mathrm{~m})$; and EV: Evissa $(550 \mathrm{~m})$ ), and three only $C$. hederifolium (MA: Martino $(300 \mathrm{~m})$; AI: Aitone $(1000 \mathrm{~m})$; and VI: Vizzavone $(1150 \mathrm{~m}))$. The pedicel of each leaf was followed to its insertion on the tuber to be sure that closely adjacent leaves were sampled from the same genotype. Horizontal starch gel electrophoresis was performed on crude protein extracts of leaf tissue. Enzyme extraction was carried out by grinding the leaf material with a Tris- $\mathrm{HCl}$ extraction buffer (Affre, 1996), and centrifuging the homogenate (20 $\min$ at $15000 \mathrm{~g}$ ). The supernatant was then either immediately absorbed on Whatman no. 3 paper wicks $(3 \times 10 \mathrm{~mm})$ and loaded onto gels, or stored at $-80^{\circ} \mathrm{C}$ prior to electrophoresis. Electrophoresis (11-12 per cent $\mathrm{w} / \mathrm{v})$ was conducted in a cold 
chamber at $4^{\circ} \mathrm{C}$ on crude protein extract of leaf tissue (see Affre, 1996).

For 12 enzyme systems investigated, seven (10 enzyme loci) showed reliable results. The 10 enzyme loci analysed were one glutamic-oxaloacetic transaminase (GOT, EC 2.6.1.1), one malate dehydrogenase (MDH, EC 1.1.1.37), one leucine aminopeptidase (LAP, EC 3.4.11.1), one phosphoglucoisomerase (PGI, EC 5.3.1.9), three phosphoglucomutases (PGM, EC 5.4.2.2), two $\alpha$-esterase ( $\alpha$ EST, EC 3.1.1.2), and one phosphogluconate dehydrogenase (PGD, EC 1.1.1.44). Nine of these loci were readable for $C$. repandum ( $\alpha E S T-2 \mathrm{did}$ not show any bands) and eight were readable for $C$. hederifolium ( $\alpha E S T-1$ and PGM-3 showed no bands).

Genetic interpretation of electrophoretic variants was based on progeny arrays of controlled crosses (Affre, 1996). The number of independent banding zones as well as the banding patterns within each variable zone were largely consistent with expected enzyme substructure and compartmentalization for diploid inheritance and were treated as such in our analyses. Where more than one isozyme of a given enzyme was observed on a gel, they were considered to be the gene products of different loci and the loci were numbered sequentially with the most anodally migrating loci designated as 1 . For each locus, the most frequent allele was assigned the index value 1.00 , and other indices were calculated as relative migration distances.

To assess genetic variability, allele frequencies, percentage of polymorphic loci $(0.95$ criterion $)$, mean number of alleles per locus, and the mean observed and unbiased expected panmictic heterozygosities were computed using BIOSYs-1 (Swofford \& Selander, 1981). Fixation indices $(F)$ were calculated from the relationship, $F=1-\left(H_{\mathrm{o}} H_{\mathrm{e}}\right)$, where $H_{\mathrm{o}}$ and $\mathrm{H}_{e}$ are, respectively, the observed and expected heterozygosity under Hardy-Weinberg equilibrium. A $\chi^{2}$-test for conformance to Hardy-Weinberg equilibrium was calculated for fixation indices using the Levene (1949) correction for small sample size. Population structure was quantified using Wright's (1965) $F$-statistics according to the protocol of Weir \& Cockerham (1984). Using the computer program FSTAT (Goudet, 1995), we calculated three genetic parameters, namely 'capf' $\left(F_{\mathrm{IT}}\right)$, the overall fixation index, 'smallf' $\left(F_{\mathrm{IS}}\right)$, the fixation index arising from nonrandom mating within populations, and $\theta\left(F_{\mathrm{ST}}\right)$, the fixation index arising from population differentiation. Use of this method allowed us to test whether these statistics were significantly different from zero. To estimate gene flow among populations or the inter-population number of immigrants per generation $(\mathrm{Nm})$ we used the relationship $F_{\mathrm{ST}}=1 /(4 N m+1)$, where $N$ is the local population size and $m$ is the average rate of immigration (Wright, 1951; Slatkin, 1987). The proportion of total $\left(H_{\mathrm{T}}\right)$ genetic diversity distributed within $\left(H_{\mathrm{S}}\right)$ and among $\left(G_{\mathrm{ST}}\right)$ populations weighted by the effective number of individuals was calculated following Prentice \& White (1988). Unbiased genetic distances among all populations were calculated following Nei $(1972,1973,1978)$ and the $\chi^{2}$ (Balakrishnan \& Sanghvi, 1968) methods because of the presence of rare alleles.

\section{Results}

\section{Allele frequency variation and genetic diversity}

Three enzyme loci (LAP-1, PGM-1 and PGM-2) were monomorphic in $C$. repandum. GOT-1 showed banding patterns consistent with a duplicated dimeric enzyme, hence this locus was excluded from analyses. No bands were observed at the $\alpha E S T-2$ locus, which is polymorphic in $C$. hederifolium. The five remaining loci $(M D H-1, P G I-1, P G M-3, \alpha E S T-1$ and $P G D-1)$ were polymorphic and used in the analysis.

In $C$. hederifolium, GOT-1 was the only monomorphic locus, PGI-1 showed banding patterns consistent with a duplicated monomeric enzyme and was excluded from analyses, and no bands were observed at the $P G M-3$ and $\alpha E S T-1$ loci that are polymorphic in $C$. repandum. The six remaining loci (MDH-1, PGM-1, PGM-2, $\alpha E S T-2, P G D-1$ and $L A P-1)$ were polymorphic. Allele frequencies at four loci (MDH-1, PGD-1, LAP-1, and either $\alpha E S T-1$ or $\alpha E S T-2)$ are shown in Fig. 1. Over all loci, $C$. hederifolium showed greater genetic variation than $C$. repandum (Table 1), the former having a greater percentage of polymorphic loci (58.93 per cent compared with 42.85 per cent), more alleles per locus (1.88 compared with 1.71) and a greater observed heterozygosity $(0.135$ compared with 0.072).

Cyclamen hederifolium showed greater allele frequency variation at the $M D H-1$ locus than $C$. repandum (Fig. 1a). For $C$. repandum, the $M D H-1-1.29$ allele was specific to the high-altitude Restonica and Vecchio populations. The RE- and VE-populations of $C$. repandum were the only polymorphic populations for the PGI-1 locus and the only monomorphic populations for the PGM-3 locus. There was more allele frequency variation at the $\alpha E S T-1$ locus in $C$. repandum than at the $\alpha E S T-2$ locus in C. hederifolium (Fig. 1b). The $\alpha E S T-1-0.98$ 
(a)
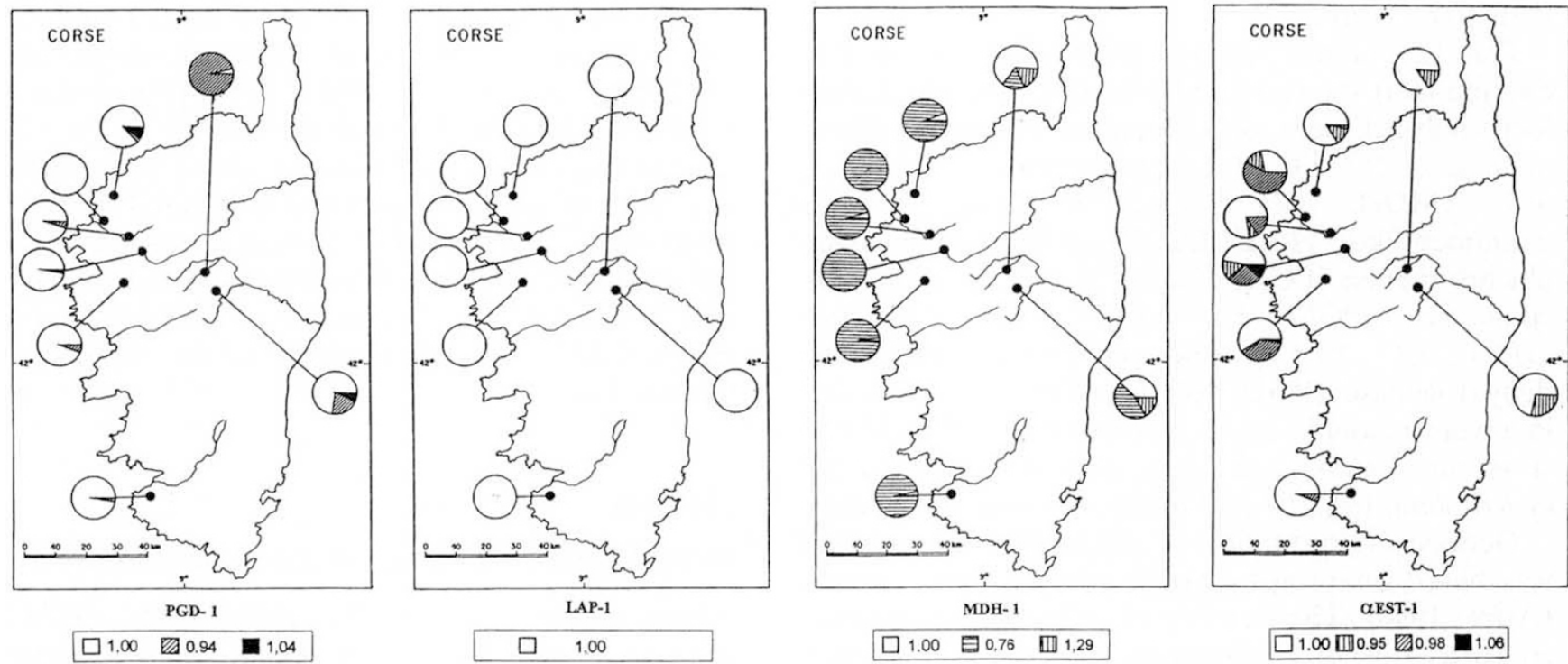

(b)
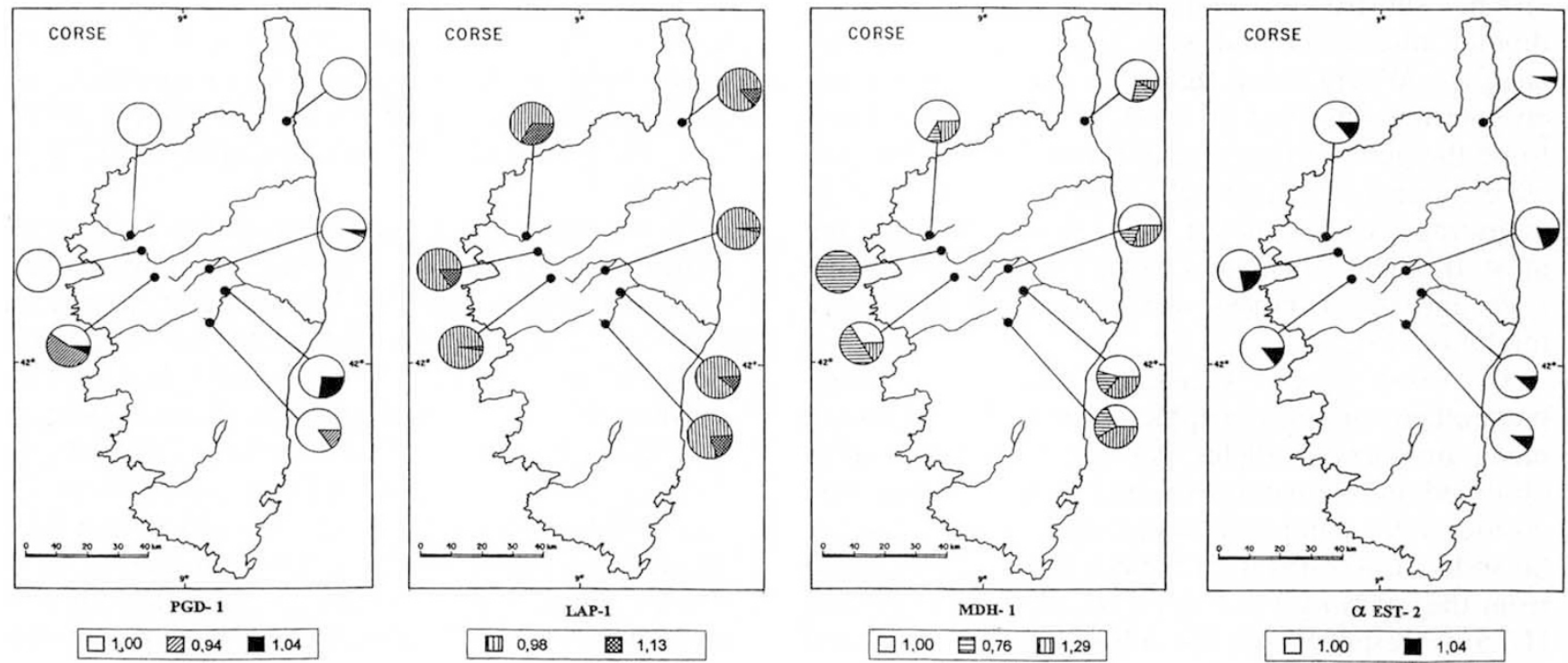

Fig. 1 Representation of allele frequencies at (a) three polymorphic loci and one monomorphic locus in eight populations of Cyclamen repandum and (b) four polymorphic loci in seven populations of $C$. hederifolium on Corsica.

allele was not found in either the RE- or VE-populations in $C$. repandum. At the $P G D-1$ locus, one population of $C$. repandum $(\mathrm{CA})$ and three populations of $C$. hederifolium (BF, HF and MA) were fixed for a single allele. All populations of $C$. repandum were monomorphic at the $L A P-1$ locus which was polymorphic in all populations of $C$. hederifolium. In general, $C$. repandum showed a much greater degree of within-population allele fixation at individual loci than $C$. hederifolium (Fig. 1b).

\section{Heterozygote deficiency}

Over all combinations of loci and populations, $C$. repandum showed greater heterozygote deficiency than $C$. hederifolium, 79.3 per cent of the polymorphic loci showing significant heterozygote deficiency in $C$. repandum compared with 47.2 per cent in $C$. hederifolium (Table 2). The RE- and VE-populations in $C$. repandum exhibited higher (significant) fixation indices than the other populations because 
Table 1 Summary of genetic variability in the eight sampled populations of $C$. repandum and the seven sampled populations of $C$. hederifolium on Corsica. Values in parentheses are one standard error. Sample sizes are the range of sampled individuals across polymorphic loci

\begin{tabular}{|c|c|c|c|c|c|}
\hline \multirow[b]{2}{*}{ Populations } & \multirow[b]{2}{*}{ Sample size } & \multirow[b]{2}{*}{$\begin{array}{c}\text { Percentage of } \\
\text { polymorphic loci } \dagger\end{array}$} & \multirow[b]{2}{*}{$\begin{array}{l}\text { Mean no. } \\
\text { of alleles per locus }\end{array}$} & \multicolumn{2}{|c|}{ Mean heterozygosity } \\
\hline & & & & Direct-count & $\begin{array}{l}\text { Hdy-Wby } \\
\text { expected } \neq\end{array}$ \\
\hline \multicolumn{6}{|l|}{ C. repandum } \\
\hline $\mathrm{BF}$ & $37-39$ & 57.14 & $1.71(0.29)$ & $0.089(0.084)$ & $0.152(0.076)$ \\
\hline $\mathrm{HF}$ & $23-33$ & 28.57 & $1.71(0.42)$ & $0.071(0.061)$ & $0.156(0.100)$ \\
\hline VE & $15-36$ & 57.14 & $1.86(0.34)$ & $0.048(0.038)$ & $0.257(0.097)$ \\
\hline RE & $19-33$ & 42.86 & $1.71(0.29)$ & $0.020(0.020)$ & $0.143(0.073)$ \\
\hline $\mathrm{PO}$ & 33 & 28.57 & $1.57(0.20)$ & $0.087(0.087)$ & $0.095(0.058)$ \\
\hline $\mathrm{CA}$ & 21 & 28.57 & $1.43(0.30)$ & $0.116(0.116)$ & $0.154(0.100)$ \\
\hline NI & 31 & 57.14 & $1.86(0.34)$ & $0.088(0.088)$ & $0.153(0.064)$ \\
\hline $\mathrm{EV}$ & $31-34$ & 42.86 & $1.86(0.40)$ & $0.055(0.055)$ & $0.146(0.078)$ \\
\hline Mean & & 42.85 & $1.71(0.05)$ & $0.072(0.011)$ & $0.157(0.016)$ \\
\hline \multicolumn{6}{|c|}{ C. hederifolium } \\
\hline $\mathrm{BF}$ & $18-27$ & 50.00 & $1.63(0.26)$ & $0.120(0.082)$ & $0.169(0.075)$ \\
\hline HF & $10-18$ & 37.50 & $1.38(0.18)$ & $0.174(0.089)$ & $0.135(0.067)$ \\
\hline VE & $50-58$ & 75.00 & $2.13(0.30)$ & $0.153(0.051)$ & $0.274(0.076)$ \\
\hline RE & $34-40$ & 62.50 & $2.13(0.30)$ & $0.178(0.057)$ & $0.231(0.077)$ \\
\hline MA & $29-30$ & 62.50 & $1.88(0.30)$ & $0.071(0.036)$ & $0.173(0.071)$ \\
\hline $\mathrm{AI}$ & 30 & 50.00 & $2.00(0.27)$ & $0.087(0.053)$ & $0.259(0.093)$ \\
\hline VI & $37-39$ & 75.00 & $2.00(0.27)$ & $0.164(0.061)$ & $0.309(0.086)$ \\
\hline Mean & & 58.93 & $1.88(0.10)$ & $0.135(0.016)$ & $0.221(0.024)$ \\
\hline
\end{tabular}

$\uparrow$ A locus is considered polymorphic if the frequency of the most common allele does not exceed 0.95 .

\$Unbiased estimate (Nei, 1978).

Table 2 Fixation indices $(F)$ (a) at five polymorphic loci in populations of $C$. repandum and (b) at six polymorphic loci in populations of $C$. hederifolium on Corsica

(a)

\begin{tabular}{|c|c|c|c|c|c|c|c|c|}
\hline Locus & $\mathrm{BF}$ & $\mathrm{HF}$ & VE & RE & PO & $\mathrm{CA}$ & $\mathrm{NI}$ & EV \\
\hline$M D H-1$ & $1.000^{* * *}$ & $-\dagger$ & $0.572 * * *$ & $0.730^{* * *}$ & $1.000^{* * *}$ & $-t$ & $1.000^{* * *}$ & $1.000^{* * *}$ \\
\hline$P G I-1$ & $-t$ & $-\dagger$ & $1.000^{* * *}$ & $1.000^{* * *}$ & $-\dagger$ & -4 & $-\dagger$ & -+ \\
\hline$P G M-3$ & -0.233 & -0.278 & $-t$ & $-t$ & $-0.435^{*}$ & $-0.680^{* *}$ & $-0.442^{*}$ & -0.240 \\
\hline$\alpha E S T-1$ & $0.932 * * *$ & $0.910^{* * *}$ & $1.000^{* * *}$ & $1.000^{* * *}$ & $1.000^{* * *}$ & $1.000^{* * *}$ & $1.000^{* * *}$ & $1.000^{* * *}$ \\
\hline $\begin{array}{l}P G D-1 \\
\text { (b) }\end{array}$ & $1.000 * * *$ & $1.000 * * *$ & $0.840 * * *$ & $1.000 * * *$ & $1.000 * * *$ & $-\dagger$ & $1.000^{* * *}$ & $1.000^{* * *}$ \\
\hline Locus & $\mathrm{BF}$ & $\mathrm{HF}$ & VE & RE & MA & AI & VI & \\
\hline$M D H-1$ & $1.000^{* * *}$ & 一† & $0.856^{* * *}$ & $0.658^{* * *}$ & $0.924^{* * *}$ & $1.000^{* * *}$ & $0.766^{* * *}$ & \\
\hline$P G M-1$ & -0.080 & -0.440 & $-0.275^{*}$ & -0.212 & $0.930^{* * *}$ & $1.000^{* * *}$ & $0.741^{* * *}$ & \\
\hline$P G M-2$ & $-\dagger$ & $-\dagger$ & $0.643^{* * *}$ & $0.263^{* *}$ & -0.055 & 0.186 & $0.290^{* * *}$ & \\
\hline$\alpha E S T-2$ & $0.413^{*}$ & -0.286 & -0.146 & -0.250 & -0.053 & 0.085 & -0.130 & \\
\hline$P G D-1$ & -+ & -† & $0.778^{* * *}$ & $0.370^{* * *}$ & $-\dagger$ & $1.000^{* * *}$ & $1.000^{* * *}$ & \\
\hline$L A P-1$ & $-0.500^{*}$ & -0.200 & -0.126 & -0.039 & -0.176 & -0.034 & -0.258 & \\
\hline
\end{tabular}

tLocus is monomorphic.

${ }^{*} P<0.05 ;{ }^{* *} P<0.01 ;{ }^{* * *} P<0.001$ indicate significant deviation from the expected heterozygosity under Hardy - Weinberg equilibrium.

(C) The Genetical Society of Great Britain, Heredity, 78, 205-214. 
of the consistent significant heterozygote deficiency across loci (Table 2). On the other hand, $C$. hederifolium showed a greater frequency of excess heterozygosity (a negative fixation index) over the studied populations (47.2 per cent of polymorphic loci) than C. repandum (only 20.7 per cent of polymorphic loci). However, only two or three of these fixation indices values were statistically significant in $C$. hederifolium and $C$. repandum, respectively.

The mean $F_{\text {IS }}$ values of 0.658 (C. repandum) and 0.329 (C. hederifolium) were both significantly different from zero $(P<0.001)$, but to a greater extent in $C$. repandum than in $C$. hederifolium (Table 3 ). The proportion of the total variation attributable to within-population diversity was greater in $C$. hederifolium ( 90 per cent of the total genetic diversity) than in $C$. repandum (60 per cent of the total genetic diversity). $F_{\text {Is }}$ values showed a significant (Pearson correlation coefficient $=0.931, \quad n=8$, $P<0.001)$ positive correlation with altitude in $C$. repandum. No such correlation was found for $C$. hederifolium.

\section{Population differentiation}

Mean $F_{\mathrm{ST}}$ and $G_{\mathrm{ST}}$ values indicate consistently greater (at least fourfold) differentiation among the populations of $C$. repandum than among populations of $C$. hederifolium (Table 3). Gene flow estimates $(\mathrm{Nm})$ were greater among populations of $C$. hederifolium $(\mathrm{Nm}=1.66)$ than among the populations of
C. repandum $(\mathrm{Nm}=0.35)$. There was no significant correlation between geographical distance and gene flow $(\mathrm{Nm})$ among populations of either species.

Based on 28 pairwise comparisons, the mean Nei and $\chi^{2}$ genetic distances among populations of $C$. repandum were greater (mean Nei distance $=$ $0.300 \pm 0.070$ and mean $\chi^{2}$ distance $=0.149 \pm 0.017$ ) than the mean genetic distances among populations of $C$. hederifolium based on 21 pairwise combinations (mean Nei distance $=0.087 \pm 0.012$ and mean $\chi^{2}$ distance $=0.116 \pm 0.007$ ). No clear geographical and genetic separation of either $C$. repandum or $C$. hederifolium populations was observed (Fig. 2), except for the genetic tree based on $\chi^{2}$ genetic distances, where the RE- and VE-populations grouped together in both species.

\section{Discussion}

Genetic diversity and mating system of C. repandum and $\mathrm{C}$. hederifolium

It is well known that genetic variability within and among populations is related to the mating system and geographical distribution in a wide range of plant species (Hamrick et al., 1979; Loveless \& Hamrick, 1984; Karron, 1987; Hamrick \& Godt, 1989). On the basis of such work, our two study species, $C$. repandum and $C$. hederifolium, by virtue of their fairly wide-ranging distribution across the northern part of the Mediterranean Basin, could be

Table 3 Summary of $F$-statistics (mean values per locus) calculated within and among populations for $C y c l a m e n$ repandum and $C$. hederifolium on Corsica

\begin{tabular}{llcccccr}
\hline Species & Locus & $F_{\mathrm{IS}}$ & $F_{\mathrm{IT}}$ & $F_{\mathrm{ST}}$ & $H_{\mathrm{S}}$ & $H_{\mathrm{T}}$ & $G_{\mathrm{ST}}$ \\
\hline C. repandum & MDH-1 & 0.740 & 0.856 & 0.447 & 0.182 & 0.326 & 0.442 \\
& PGI-1 & 1.000 & 1.000 & 0.834 & 0.060 & 0.338 & 0.822 \\
& PGM-3 & -0.361 & -0.228 & 0.098 & 0.351 & 0.354 & 0.008 \\
& $\alpha \mathrm{EST}-1$ & 0.972 & 0.976 & 0.151 & 0.399 & 0.488 & 0.182 \\
& PGD-1 & 0.941 & 0.973 & 0.548 & 0.137 & 0.316 & 0.568 \\
& Mean & $0.658^{* * *}$ & $0.715^{* * *}$ & $0.415^{* * *}$ & 0.226 & 0.364 & 0.404 \\
& SE & 0.153 & 0.090 & 0.052 & 0.064 & 0.031 & 0.143 \\
C. hederifolium & MDH-1 & 0.849 & 0.874 & 0.168 & 0.544 & 0.644 & 0.156 \\
& PGM-1 & 0.219 & 0.262 & 0.055 & 0.313 & 0.330 & 0.053 \\
& PGM-2 & 0.352 & 0.490 & 0.214 & 0.356 & 0.384 & 0.074 \\
& aEST-2 & -0.064 & -0.055 & 0.009 & 0.244 & 0.249 & 0.016 \\
& PGD-1 & 0.856 & 0.894 & 0.268 & 0.225 & 0.271 & 0.169 \\
& LAP-1 & -0.236 & -0.145 & 0.074 & 0.225 & 0.253 & 0.109 \\
& Mean & $0.329^{* * *}$ & $0.386^{* * *}$ & $0.131^{* * *}$ & 0.318 & 0.355 & 0.096 \\
& SE & 0.078 & 0.071 & 0.013 & 0.050 & 0.062 & 0.024 \\
\hline
\end{tabular}

***F-statistics significantly $(P<0.001)$ different from zero using the computer software FSTAT (Goudet, 1995). 


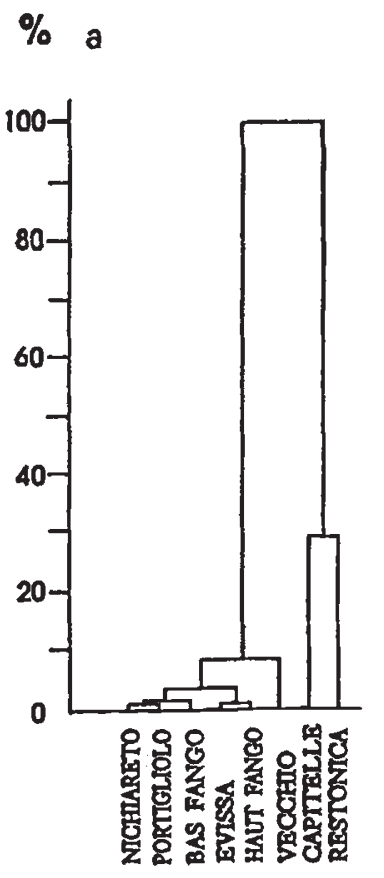

\section{$\%$ b}

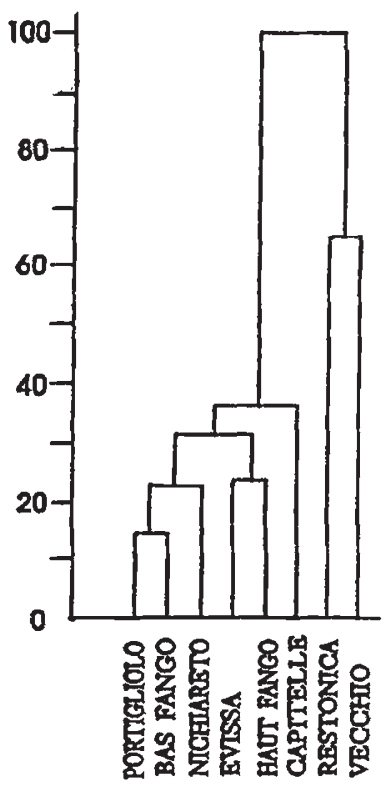

$\%$ a

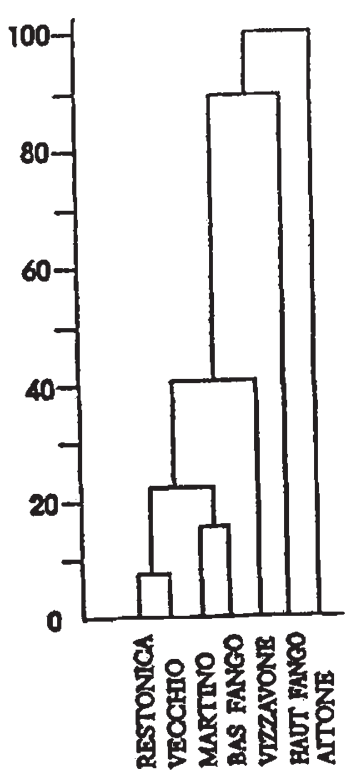

$\%$ b

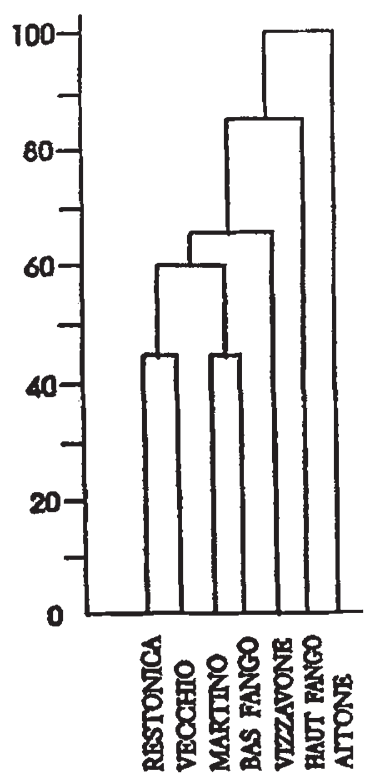

Fig. 2 Genetic distance relationships among the studied populations of each species summarized by cluster analysis using (a) Nei's and (b) $\chi^{2}$ genetic distance coefficients (given as percentages) for Cyclamen repandum (above) and $C$. hederifolium (below).

predicted to show high levels of genetic variability in natural populations.

The populations of both species sampled on the island of Corsica exhibit higher or similar average values of genetic variation to those reported for

long-lived, widespread, outcrossing animal-pollinated species (Hamrick \& Godt, 1989). Nevertheless, populations of $C$. hederifolium on Corsica contain higher levels of genetic variation than those of $C$. repandum (see Table 1 ).

The two species differ markedly in terms of both their within-population fixation indices, the mean $F_{\text {IS }}$ value in $C$. hederifolium being half that of $C$. repandum (see Table 3), and amounts of among-population differentiation, the mean $F_{\mathrm{ST}}$ and $G_{\mathrm{Sr}}$ values being greater (at least fourfold) among $C$. repandum populations than among $C$. hederifolium populations (see Table 3). The distribution of among-population genetic diversity in $C$. hederifolium (10 per cent of the total genetic diversity) is similar to the average value reported for animal-pollinated outcrossed plants (Hamrick \& Godt, 1989). For C. repandum, the among-population component of variation ( 40 per cent of the total genetic diversity) is greater than that reported for animal-pollinated, mixed-mating system species but lower than that reported for selfing species (Hamrick \& Godt, 1989).

Cyclamen repandum and $C$. hederifolium thus appear to have mixed-mating systems. Cyclamen repandum does, however, have markedly greater heterozygote deficiencies than $C$. hederifolium. Although this may be caused by greater withinpopulation substructure (Wahlund effect) in $C$. repandum this is unlikely as samples were collected over a limited area in both species. Cyclamen repandum thus appears to be markedly more inbred (either because of autogamy, geitonogamy or biparental inbreeding) than $C$. hederifolium. Given that the two species have relatively similar ecological and geographical distributions, floral traits (pendant, approach herkogamous flowers), and pollinators (syrphid flies and bumblebees), it is interesting to ask why and how such a difference in mating system may have evolved.

Obviously, determining the causes for the evolution of such variation is a particularly difficult task, but we can suggest several factors likely to be involved in the evolution and maintenance of this variation. The first, and probably the most important factor, concerns levels of inbreeding depression in the two species. In a controlled pollination experiment in an insect-free glasshouse (Affre, 1996), we have found that $C$. repandum shows no evidence of inbreeding depression on fruit maturation $(\delta=0.02)$ and seed number $(\delta=0.12)$ with a multiplicative estimate of 0.14 . In contrast, $C$. hederifolium shows higher levels of inbreeding depression on fruit maturation $(\delta=0.27)$ and seed set $(\delta=0.31)$, resulting in a multiplicative estimate of $\delta=0.49$. Such a value 
may help maintain a more outcrossed mating system than in $C$. repandum, especially if further inbreeding depression occurs at later life cycle stages. In contrast, high levels of inbreeding in $C$. repandum may have purged the genetic load responsible for inbreeding depression.

A second factor that may have caused increased levels of inbreeding in $C$. repandum concerns potential competition for pollinators when sympatric species flower at the same time (Levin, 1972; Waser, 1983). Cyclamen repandum flowers in the spring and is thus in competition with several other species for pollination (we recorded 11 other insect-pollinated species in flower in six $C$. repandum populations) (Affre, 1996). We have also observed a single Bombus species visiting $C$. repandum flowers and other species such as Allium triquetrum L. and Erica arborea L. in a single foraging bout. Cyclamen hederifolium, however, flowers in the autumn, when there are few other species in flower (we have observed six other insect-pollinated species in flower at the same time in six $C$. hederifolium populations) (Affre, 1996). Competition for pollinators may thus have stimulated a tendency towards selfing in C. repandum that has not occurred in C. hederifolium (e.g. Levin, 1972).

A third factor is that both species are pollinated by bumblebee species which vibrate the flowers in a manner typical of other buzz-pollinated plants and which visit many adjacent flowers during a foraging sequence. Hence, the potential for geitonogamous pollination and pollination among closely adjacent (related) plants is high in both species. Bumblebee visits are more frequent in $C$. repandum populations than in C. hederifolium populations (Affre, 1996). Cyclamen hederifolium is, however, more frequently visited by syrphid flies, which may travel greater distances among flowers visited. If such visits by syrphid flies do cause pollination, then this may help explain the differences between the two species in their fixation indices. This may nevertheless require some form of cryptic self-incompatibility (i.e. faster pollen tube growth of outcrossed pollen) in $C$. hederifolium.

A fourth potential factor involves the slight differences in floral morphology between the two species which may limit facilitated self-pollination in $C$. hederifolium to a greater extent than in $C$. repandum. Both species have approach herkogamous flowers (i.e. the style exceeds the stamens by at least $1.5 \mathrm{~mm}$ ), which prevents autonomous selfing (Affre, 1996). In $C$. repandum, the style extends $>1 \mathrm{~mm}$ beyond the mouth of the corolla, whereas in $C$. hederifolium the style is only slightly exserted
( $<1 \mathrm{~mm}$ ) (J. D. Thompson and L. Affre, personal observations). In $C$. repandum, it has been observed that pollen removal from the anthers and pollen deposition on stigmas are significantly positively correlated as flowers age (A. Vivat, unpublished data). Hence, individual pollinator visits may cause both pollen removal and deposition within $C$. repandum flowers. This may be because the stigma (owing to its high degree of exsertion) may be in continuous contact with visiting bumblebee bodies which hang from the flower with their ventral surface towards the interior of the flower. As pollen falls onto the bumblebee, it may be directly transferred to the stigma. In $C$. hederifolium, the stigma is far less exserted and will not be in such close and continual contact as bumblebees collect pollen. Hence, less within-flower self-pollination may occur in $C$. hederifolium. Careful observations of pollinator behaviour and data on self- and outcross-pollen deposition are needed to examine this possibility.

A final feature of the genetic diversity results is that fixation indices in $C$. repandum populations were highest in the higher altitude populations which are at the limit of the altitudinal distribution of this species. In fact, fixation indices in low altitude populations of $C$. repandum were no greater than those observed in $C$. hederifolium. This suggests that the difference between $C$. repandum and $C$. hederifolium results from increased inbreeding in $C$. repandum populations at the limits of its distribution (at higher altitude) perhaps because of reduced pollination activity. Our data thus provide an interesting example of the often predicted trend for increased inbreeding with increasing altitude (Berry \& Calvo, 1989). It would now be most interesting to compare the levels of inbreeding depression in populations varying in fixation indices and the data on population structure on Corsica with that among continental populations across the range of $C$. repandum and $C$. hederifolium.

\section{Genetic diversity and mating system in relation to geographically restricted Cyclamen species}

Restricted species may often contain significantly lower amounts of genetic variability than widespread species but may show greater genetic differentiation among populations as a result of founder effects, genetic drift, and/or inbreeding in smaller populations (Hamrick et al., 1979; Loveless \& Hamrick, 1984; Karron, 1987, 1991; Hamrick \& Godt, 1989). We can thus ask whether the geographically restricted species, $C$. balearicum and $C$. creticum, show less genetic variability and more differentiation 
Table 4 Mean genetic diversity, heterozygosity and population differentiation in Cyclamen repandum and C. hederifolium compared to C. balearicum and C. creticum (data from Affre \& Thompson, 1997; Affre et al., 1997)

\begin{tabular}{|c|c|c|c|c|c|c|}
\hline \multirow[b]{2}{*}{ Species } & \multirow{2}{*}{$\begin{array}{l}\text { Percentage of } \\
\text { polymorphic } \\
\text { loci }\end{array}$} & \multirow{2}{*}{$\begin{array}{l}\text { Mean no. } \\
\text { of alleles } \\
\text { per locus }\end{array}$} & \multicolumn{2}{|c|}{ Mean heterozygosity } & \multirow[b]{2}{*}{$F_{\mathrm{iS}}$} & \multirow[b]{2}{*}{$F_{\mathrm{ST}}$} \\
\hline & & & Direct-count & $\begin{array}{l}\text { Hdy-Wbg } \\
\text { expected }\end{array}$ & & \\
\hline C. repandum & 42.85 & $1.71 \pm 0.05$ & $0.072 \pm 0.011$ & $0.157 \pm 0.016$ & $0.658 \pm 0.153$ & $0.415 \pm 0.052$ \\
\hline C. hederifolium & 58.93 & $1.88 \pm 0.10$ & $0.135 \pm 0.016$ & $0.221 \pm 0.024$ & $0.329 \pm 0.078$ & $0.131 \pm 0.013$ \\
\hline $\begin{array}{l}\text { C. balearicum } \\
\text { (southern France) }\end{array}$ & 37.40 & $1.51 \pm 0.07$ & $0.014 \pm 0.003$ & $0.159 \pm 0.021$ & $0.866 \pm 0.074$ & $0.480 \pm 0.101$ \\
\hline $\begin{array}{l}\text { C. balearicum } \\
\text { (Balearic Islands) }\end{array}$ & 24.20 & $1.30 \pm 0.04$ & $0.006 \pm 0.003$ & $0.101 \pm 0.013$ & $0.919 \pm 0.048$ & $0.297 \pm 0.059$ \\
\hline C. creticum & 54.76 & $1.78 \pm 0.07$ & $0.053 \pm 0.011$ & $0.222 \pm 0.020$ & $0.748 \pm 0.068$ & $0.168 \pm 0.028$ \\
\hline
\end{tabular}

among populations than the widespread species, $C$. repandum and $C$. hederifolium, studied here.

Cyclamen repandum, $C$. creticum and $C$. hederifolium possess greater amounts of genetic variation than the restricted $C$. balearicum, whereas population differentiation is high in $C$. balearicum and $C$. repandum but low in $C$. hederifolium and $C$. creticum (Table 4). Cyclamen hederifolium shows much lower fixation indices than $C$. repandum and $C$. creticum, both of which show lower fixation indices than $C$. balearicum (Table 4). Previous work in controlled conditions (Affre, 1996) shows that C. balearicum can spontaneously self-pollinate in the absence of pollinators and shows little evidence of inbreeding depression on fruit maturation and seed set (multiplicative $\delta=0.09$ ). In contrast, $C$. creticum lacks the ability to self-pollinate spontaneously and shows inbreeding depression on fruit maturation and seed set (multiplicative $\delta=0.43$ ). Hence, the spontaneously selfing and geographically restricted $C$. balearicum exhibits lower amounts of genetic variation and greater genetic differentiation among populations than both widespread species, $C$. repandum and $C$. hederifolium. However, in spite of its restricted geographical distribution, $C$. creticum exhibits quite similar levels of genetic variation and lower population differentiation than $C$. repandum. There thus appears to be a gradient of increased inbreeding from $C$. hederifolium through $C$. repandum and $C$. creticum to the highly selfing $C$. balearicum. The mating system thus appears to be more important than geographical distribution in shaping the population genetic structure of these Cyclamen species.

\section{Acknowledgements}

We thank Isabelle Guyot and Alain Friedlander who helped locate $C$. hederifolium populations, France Di
Giusto, Lamjed Toumi, Michele Tarayre and Roselyne Lumaret for help and advice on electrophoresis procedures and genetic data interpretation, Christian Collin and the greenhouse staff at the C.E.F.E.-C.N.R.S. for the maintenance of plant material and Susan Mazer for advice. Le Ministère de l'Education Nationale de L'Enseignement Supérieur, de la Recherche et de l'Insertion Professionnelle (contract ACC SV3 no. 9503025) and the C.N.R.S. provided financial support.

\section{References}

AFFre, L. 1996. Variation du Système de Reproduction et Struturation Génétique des Populations Chez Quatre Espèces du Genre Cyclamen (Primulaceae). Thèse, Université des Sciences François Rabelais de Tours, France.

AfFre, L. AND THOMPSON, J. D. 1997. Population genetic structure and levels of inbreeding depression in the Mediterranean island endemic Cyclamen creticum (Primulacea). Biol. J. Linn. Soc. (in press).

AFFRE, L., THOMPSON, J. D. AND DEBUSSCHE, M. 1997. Genetic structure of continental and island populations of the Mediterranean endemic Cyclamen balearicum (Primulacea) Am. J. Bot. (in press).

ANDERBERG, A. A. 1993. Phylogeny and subgeneric classification of Cyclamen L. (Primulaceae). Kew Bulletin, 49, 455-467.

BALAKRISHNAN, V. AND SANGHVl, L. D. 1968. Distance between populations on the basis of attribute data. Biometrics, 24, 859-865.

BENNETT, S. T. AND GRIMSHAW, J. M. 1991. Cytological studies in Cyclamen subg. Cyclamen (Primulaceae). Pl. Syst. Evol., 176, 135-143.

BERRY, P. E., AND CALVO, R. N. 1989. Wind pollination, self-incompatibility, and altitudinal shifts in pollination systems in the high Andean genus Espeletia (Asteraceae). Am. J. Bot., 76, 1602-1614.

GOUDET, J. 1995. Fstat version 1.2: a computer program to 
calculate F-statistics. J. Hered., 86, 485-486.

GREY-wilson, c. 1988. The genus Cyclamen. A Kew Magazine Monograph. Portland, Oregon.

HAMRICK, J. L. AND GODT, M. J. W. 1989. Allozyme diversity in plant species. In: Brown, A. H. D., Clegg, M. T., Kahler, A. L. and Weir, B. S. (eds) Plant Population Genetics, Breeding and Genetic Resources, pp. 43-63. Sinauer, Sunderland, MA.

HAMRICK, J. L., LINHART, Y. B. AND MITTON, J. B. 1979. Relationships between life history characteristics and electrophoretically detectable genetic variation in plants. Ann. Rev. Ecol. Syst., 10, 173-200.

KARRON, J. D. 1987. A comparison of levels of genetic polymorphism and self-compatibility in geographically restricted and widespread plant congeners. Evol. Ecol., $1,47-58$.

KARRON, J. D. 1991. Patterns of genetic variation and breeding systems in rare plant species. In: Falk, D. A. S. and Holsinger, K. E. (eds) Genetics and Conservation of Rare Plants, pp. 87-98. Oxford University Press, Oxford.

LEVENE, H. 1949. On a matching problem arising in genetics. Ann. Math. Statist., 20, 91-94.

LEVIN, D. A. 1972. Competition for pollinator service: a stimulus for the evolution of autogamy. Evolution, 26, 668-674.

LINHART, Y. B. AND PREMOLI, A. C. 1993. Genetic variation in Aletes acaulis and its relative, the narrow endemic $A$. humilis (Apiaceae). Am. J. Bot., 80, 598-605.

LOVELESS, M. D. AND HAMRICK, J. L. 1984. Ecological determinants of genetic structure in plant populations. Ann. Rev. Ecol. Syst., 15, 65-95.

NEI, M. 1972. Genetic distance between populations. Am.
Nat., 106, 283-292.

NEI, M. 1973. Analysis of gene diversity in subdivided populations. Proc. Natl. Acad. Sci., U.S.A., 70, 3321-3323.

NE1, M. 1978. Estimation of average heterozygosity and genetic distance from a small number of individuals. Genetics, 89, 583-590.

PRENTICE, H. C. AND WHITE, R. J. 1988. Variability, population size and isolation: the structuring of diversity in Öland Gypsophila fastigiata. Acta Oecol./Oecol. Plant., 9, 19-29.

PRIMACK, R. B. 1980. Phenotypic variation of rare and widespread species of Plantago. Rhodora, 82, 87-95.

SLATKIN, M. 1987. Gene flow and the geographic structure of natural populations. Science, 236, 787-792.

SWOFFORD, D. L. AND SELANDER, R. B. 1981. BIOSYS-1. $A$ Computer Program for the Analysis of Allelic Variation in Genetics. User's Manual. University of Illinois, Urbana, IL.

WASER, N. M. 1983. Competition for pollination and floral character differences among sympatric plant species: A review of evidence. In: Jones, C. E. and Little, R. J. (eds) Handbook of Experimental Pollination Biology, pp. 277-293. Van Nostrand Reinhold Company Inc., New York.

WElR, B. S. AND COCKERHAM, C. C. 1984 . Estimating $F$-statistics for the analysis of population structure. Evolution, 38, 1358-1370.

WRIGHT, s. 1951. The genetical structure of populations. Ann. Eugen., 15, 323-354.

WRIGHT, s. 1965 . The interpretation of population structure by F-statistics with special regard to mating systems. Evolution, 19, 395-420. 